\title{
PENGARUH FAKTOR-FAKTOR PRODUKSI TERHADAP PEMBAPATAN BAWANG MERAH DIDESA LAPANDEWA KAINDEA KECAMATAN LAPANDEWA KABUPATEN BUTON SELATAN
}

\author{
La Ode Muhammad Mustari
}

\author{
Program Studi Agribisnis Fakultas Pertanian \\ Universitas Muhammadiyali Buton \\ Jln. Betoambari No. 36 Baubau \\ e-mail: laodemustari2019@gmail.com
}

\begin{abstract}
The problem statement in this research is: Whether the factors of production (land area and seeds) affect the income of shallot farming in Lapandewa Kaindea, Lapandewa sub-district, South Buton Regency? The purpose of this study was to determine whether the factors of production (Land area and seeds) affect the income of onion farming in Lapandewa Kaindea Village, Lapandewa Sub-district, South Buton Regency. The Population of this study is the onion farmers in Lapandewa Kaindea Village, Lapandewa sub-district, South Buton Regency. The researcher's sample took was 32 farmers. Data were collected through interviews using questionnaires and analyzed using income analysis. Based on the results of the study, it was concluded that farmers in Lapandewa Kaindea Village, Lapandewa District, South Buton Regency, were the factors of production in the form of costs (labor, seeds, and fertilizer) that significantly affected the red onion farming income. With an $R 2$ value of 0.981 . This means that the factors of production in the form of (labor, seeds, and fertilizer) have an effect of $98.10 \%$ only, the rest is influenced by other factors not discussed in this study. Recommendations on the part of the government are expected to give more attention to farmers, both in the form of handling fertilizer prices, fertilizer and fake fertilizer distribution.
\end{abstract}

Keywords: Effect of production factors, revenue, onion

\begin{abstract}
Abstrak
Rumusan masalah penelitian adalah: Apakah faktor-faktor produksi. (luas lahan dan benih) berpengaruh terhadap pendapatan usahatani bawang merah di Lapandewa Kaindea Kecamatan Lapandea Kabupaten Buton Selatan? Tujuan penelitian ini untuk mengetahui Apakah faktor-faktor produksi (luas lahan dan benih) berpengaruh terhadp pendapata usahatani bawang merah di Desa Lapandewa Kaindea Kecamatan Lapandewa Kabupaten Buton Selatan. Populasi dari penelitian ini adalah petani bawang merah yang ada di Desa Lapandewa Kaindea Kacematan Lapandewa Kabupaten Buton Selatan, sampel penelitian mengambil 32 petani bawang merah. Data dikumpulkan melalui wawancara dengan menggunakan daftar pertanyaan dan dianalisis dengan menggunakan analisis pendapatan, analisis perbandingan serta analisis regresi. Berdasarkan hasil penelitian disimpulkan bahwa petani di Desa Lapandewa Kaindea Kecamatan Lapandewa Kabupaten Buton Selatan adalah Faktor-faktor produksi berupa biaya (tenaga kerja, benih dan pupuk) berpengaruh nyata terhadap pendapatan usahatani bawang merah. Dengan Nilai $\mathrm{R}^{2}$ sebesar $0,981 \mathrm{Hal}$ ini berarti faktor-faktor produksi berupa (tenaga kerja, benih dan pupuk) memberikan pengaruh sebesar $98,10 \%$ saja, sisanya dipengaruhi oleh faktor lain yang tidak dibahas dalam penelitian ini. Rekomendasi di pihak pemerintah diharapkan memberikan perhatian lebih kepada petani, baik itu berupa penanganan masalah harga pupuk, distribusi pupuk maupun pupuk palsu.
\end{abstract}

Kata Kunci: Pengaruh Faktor-Faktor Produksi, Pendapatan, bawang merah 


\section{Journal of Agribusiness Media}

Vol. 1 Issue 1, November 2017

P-ISSN: 2527-8479

\section{PENDAHULUAN}

Indonesia selama ini dikenal sebagai negara yang memiliki sumber aaya alam yang meiimpan, sehingga sering disebut sebagai negara agraris yang berarti negara yang mengandalkan sektor pertanian baik sebagai sumber mata pencaharian maupun sebagai penopang pembangunan. Di Indonesia sektor pertanian dibagi menjadi lima subsektor yaitu subsektor pertanian pangan, subsektor perkebunan, subsector kehutanan, subsektor petemakan dan subsektor perikanan. Sektor pertanian terus dituntut berperan dalam perekonomian nasional melalui pembentukan Produk Domestik Bruto (PDB), perolehan devisa, penyediaan pangan dan banan baku industri, pengentasan kemiskinan, penyediaan lapangan kerja dan peningkatan pendapatan masyarakat.

Pengembangan usahatani bawang merah perlu dilakukan terkait dengan kebutuhan konsumsi bawang merah seiring meningkatnya jumlah penduduk. Oleh karena ituusahatani bawang merah diarahkan untuk dapal memacu peningkatan produktivitasnya. Namun, yang terjadi adalah produktivitas bawang merah selama 4 tahun terakhir (2005-2008) selalu menurun tiap tahunnya dengan rata-rata penurunan 15,96 persen per tahun. Nilai produktivitas ini masih tergolong rendah dan masih berpeiuang untuk ditingkatkan karena berdasarkan hasil penelitian Tety Suciaty (2004) faktor bibit memegang peranan yang penting untuk menunjang keberhasilan produksi tanaman, selain itu juga penggunaan bibit yang bermututinggi merupakan langkah awal peningkatan produksi. Pupukmerupakan sarana produksi yang sangat penting, pemberian pupuk yang tepat dan berimbang akan menghasilkan tanaman denganproduksi yang tinggi. Faktor produksi fungisida dan insektisida juga memegang peranan yang penting dalam mempengaruhi jumlah produksi, sampai saat ini penggunaan fungisida dan insektisida merupakan cara yang paling banyak digunakan dalam pengendalian serangan serangga pada tanaman dan juga nama yang disebabkan karena penyakit jamur. Hal ini karena penggunaan fungisida serta insektisida merupakan cara yang paling mudah dan efektif, dengan penggunaan fungisida serta insektisida yang efektif akan memberikan hasil yang memuaskan sehingga tanaman dapat berproduksi secara optimal, disamping itu faktor produksi tenaga kerja bersama-sama dengan factor produksi yang lain, bila dimanfaatkan secara optimal akan uapat rneningkatkan ptouuicsi secara maksimal. Setiap penggunaan tenaga kerja produktif hamper selalu dapat rneningkatkan produksi.

Upaya rneningkatkan produksi bawang merah dapat ditempuh melalui usaha budidaya yang baik usahatani bawang merah merupakan saiah satu jenis usahatani di bidang pertanian tanaman pangan yang mempunyai peluang untuk dikembangkan dalam peningkatan intensitas produksi di Indonesia. Bawang merah memiliki peranan penting dalam usaha rneningkatkan produksi pertanian untuk memenuhi kebutuhan pangan dan gizi serta memenuhi kebutuhan pasar dalam dan luar negeri, memperluas kesempatan kerja, rneningkatkan pendapatan dan kesejahteraan petani.

Tingkat produktivitas per satuan luas, merupakan cerminan tingkat penerapan teknologi usaha tani, baik penggunaan bibit, luas lahan, tenaga kerja, pemupukan, terutarna penggunaan pupuk Urea. Peningkatan produksi terlihat lambat dari tahun ketahun, selama lima tahun terakhir rata-rata peningkatan produktivitas hanya $0.1 \%$ /tahun. Hal ini mencerminkan betapa beratnya upaya peningkatan produksi melalui peningkatan produktivitas. Luas tanam, Luas 
panen dan produksi bawang merah di Kabupaten Buton Selatan dan Kecamatan Lapandewa tiga tahun terakhir seperti pada tabel 1 dan 2 .

Tabel 1. Luas Lahan, Luas Panen Dan Produksi Bawang Merah Tahun 2014-2012 Di Kabupaten Buton.

\begin{tabular}{cccc}
\hline Tahun & Luas Tanam $(\mathrm{Ha})$ & Luas Panen $(\mathrm{Ha})$ & Produksi (Ton) \\
\hline Tahun 2014 & 45 & 30 & 282 \\
\hline Tahun 2013 & 48 & 32 & 285 \\
\hline Tahun 2012 & 54 & 36 & 301 \\
\hline
\end{tabular}

Sumber Data: Dinas Pertanian Kabupaten Buton, 2014.

Tabel 2. Luas lahan, luas panen dan produksi bawang merah tahun 2014-2012 di kecamatan lapandewa Kabupaten Buton Selatan.

\begin{tabular}{cccc}
\hline Tahun & Luas Tanam $(\mathrm{Ha})$ & Luas Panen $(\mathrm{Ha})$ & Produksi (Ton) \\
\hline Tahun 2014 & 20 & 10 & 191 \\
\hline Tahun 2013 & 22 & 11 & 195 \\
\hline Tahun 2012 & 24 & 13 & 213 \\
\hline
\end{tabular}

Sumber Data: Dinas Petanian Kabupaten Buton, 2014.

Tabel 1 dan 2 di atas tersebut menunjukkan bahwa produksi bawang merah dari tahun 2012 sampai dengan 2014 mengalami penurunan hal ini disebabkan adanya perubahan iklim yang tidak menentu, hama penyakit dan kurang optimalnya petugas penyuluh dalam memberikan arahan kepada petani serta benih yang tidak sesuai yang diharapkan oleh petani.

Hasil observasi awal menunjukan bahwa masih adanya serangan penganggu tanaman, belum optimalnya sarana produksi (benih), belum optimalnya petugas dalam memberikan penyuluhan dan kurangnya kesadaran petani dalam memasarkan hasil pertanian. Produksi yang tinggi dari hasil yang diperoleh para petani mempunyai altematif untuk memasarkan hasil produksinya seperti para pedagang pengumpul. Nairran diharapkan petani mampu membaca situasi agar produktivitas yang diperoleh memberikan kontribusi bagi pendapatan petani.

Berdasarkan paparan yang dikemukakan di atas hal penting yang perlu diperhatikan antara kenyataan (masaiah) aiatas dan harapan, sehingga penulis tertarik menggangkat judul Analisis faktor-faktor produksi terhadap pendapatan usahatani bawang merah di Desa Lapendewa Kaindea Kecamatan Lapandewa Kabupaten Buton Selatan.

Berdasarkan uraian latar belakang yang dijelaskan di atas, maka diidentifikasi masalah yaitu: Apakah faktor-faktor produksi (luas lahan dan benih) berpengaruh terhadap pendapatan usahatani bawang merah di Lapendewa Kaindea Kecamatan Lapandewa Kabupaten Buton Selatan?

Penelitian ini bertujuan untuk mengetahui Apakah faktor-faktor produksi (luas lahan dan benih) berpengaruh terhadap pendapatan usahatani bawang merah di Lapendewa Kaindea Kecamatan Lapandewa Kabupaten Buton Selatan adalah? 


\section{Journal of Agribusiness Media}

Vol. 1 Issue 1, November 2017

P-ISSN: 2527-8479

Adapun hasil penelitian adalah untuk:

1. Hasil penelitian diharapkan dapat memberikan sumbangan pemikiran bagi petani bawang merah dalam rangka memberdayakan kemampuan faktor-faktor input agribisnis dalam mempengaruhi produksi usahatani bawang merah.

2. Menjadi bahan masukan bagi pengambil kebijakan, kalangan swasta dan usahawan dalam upaya peningkatan kemampuan faktor-faktor input agribisnis dalam mempengaruhi tingkat produksi usahatani bawang merah.

3. Hasil penelitian ini di harapkan dapat menjadi bahan informasi bagi penelitian yang lain, tentang pemberdayaan faktor-faktor input dalam mempengaruhi tingkat produksi usahatani bawang merah.

\section{METODE PENELITIAN}

Penelitian ini dilakasanakan di Lapendewa Kaindea Kecamatan Lapandewa Kabupaten Buton Selatan, mulai bulan juni sampai dengan Juli 2015. Populasi dari penelitian ini adalah petani yang melakukan budidaya bawang merah yang ada Lapendewa Kaindea Kecamatan Lapandewa Kabupaten Buton Selatan. Sampel penelitian mengambil 20\% dari total petani 160 orang sehingga diambil sampel sebanyak 32 orang petani. Menurut Sugiyono (1998) jika populasi diatas 100 orang maka dapat dilakukan sampel 20\%-30\%, namum jika populasi dibawah 100 orang maka dilakukan sampel seluruhnya.

Teknik pengambilan data dalam penelitian ini alat pengumpulan data terdiri atas:

1. Menggunakan kuesioner atau angket. Masyarakat yang menjadi objek penelitian diperoleh datanya denganmenggunakan kuesioner yang telah disusun sedemikian rupa sehingga data yang dibutuhkan dapat diperoleh secara maksimal. Kuesioner menurut Soemarjan dan Koentjaraningrat (1981), merupakan suatu daftar yang berisikan suatu rangkaian pertanyaan mengenai sesuatu hal atau dalam sesuatu bidang (Koentjaraningrat, 1981).

2. Observasi. Observasi atau pengamatan langsung dilakukan untuk mencocokkan data dan Informasi yang didapatkan dari hasil wawancara dengan keadaan sebenamya di lapangan.

3. Studi perpustakaan. Pengumpulan data melalui berbagai referensi yang terkait erat dengan objek penelitian.

Variabel yang diamati dalam penelitian ini adalah:

1. Identitas responden yang meliputiumur, tingkat pendidikan, jumlah tanggungan keluarga, pengalaman berusahatani bawang merah.

2. Keadaan usahatani meliputi luas lahan, status pemilikan lahan, biaya produksi, jumlah produksi dan pendapatan usahatani.

3. Biaya luas lahan $\left(\mathrm{X}_{1}\right)$ dan benih $\left(\mathrm{X}_{2}\right)$.

Teknik Analisa data yang diperoleh dari penelitian ini ditabulasi selanjutnya dianalisis secara deskriptif kuantitatif. Dimana analisis yang digunakan adalah analisis regresi linier berganda dengan menggunakan teknik korelasi product moment dengan program SPSS 19.0 for windows. Pendapatan sebagai variabel terikat, sedangkan tenaga kerja, benih unggul dan pupuk sebagai variabel bebas. Rumus yang digunakan adalah :

$$
Y=a+b_{1} X_{1}+b_{2} X_{2}
$$

(Hasan, 2002)

Dimana :

$\mathrm{Y} \quad=$ Pendapatan $(\mathrm{Rp})$ 


\section{Journal of Agribusiness Media}

Vol. 1 Issue 1, November 2017

P-ISSN: 2527-8479

a $=$ parameter intercept

$\mathrm{b}_{1}, \mathrm{~b}_{2}, \mathrm{~b}_{3}=$ parameter koefisien regresi

$\mathrm{X}_{1} \quad=$ luas lahan (ha)

$\mathrm{X}_{2}=\operatorname{Benih}(\mathrm{Rp} / \mathrm{ha})$

Untuk menguji pengaruh pengaruh variabel bebas secara serempakterhadap produksi, digunakan uji $\mathrm{F}$ dengan kriteria uji sebagai berikut:

Jika $\mathrm{F}_{\text {hitung }}<\mathrm{F}_{\text {tabel }}$ : maka terima $\mathrm{H}_{0}$ atau tolak $\mathrm{H}_{1}$

Jika $\mathrm{F}_{\text {hitung }}>\mathrm{F}_{\text {tabel }}$ : maka terima $\mathrm{H}_{1}$ atau tolak $\mathrm{H}_{0}$

Definisi operasional dalam penelitian ini adalah:

a. Produksi usaha tani bawang merah adalah banyaknya produk yang dihasilkan (Ton atau $\mathrm{kg})$.

b. Luas lahan merupakan ukuran besarnya lahan yang menjadi lahan (Ha).

c. Pendapatan adalah hasil bersih yang diperoleh petani setelah dikurangi dengan total biaya yang dikeluarkan (Rupiah).

d. Biaya total adalah semua biaya (baik biaya tetap maupun biaya tidak tetap) yang dikeluarkan petani dalam proses produksinya $(\mathrm{Rp})$.

e. Biaya tetap (fixed cost) adalah biaya yang dikeluarkan petani yang jumlahnya tidak berubah walaupun jumlah produksi berubah (Rp).

f. Biaya tidak tetap (variabel cost) merupakan biaya yang jumlahnya berubah tergantung besar kecilnya jumlah produksi (Rp).

g. Jumlah Jam Kerja merupakan banyaknya waktu (jam) kerja yang digunakan dalam pengelolaan usahatani dalam satu musim tanam yang dinyatakan dalam hari orang kerja (HOK).

h. Benih adalah Adalah jumlah benih bawang merah yang digunakan pada saat tanam (kg/musim tanam).

\section{HASIL DAN PEMBAHASAN}

\section{Pengaruh Faktor-Faktor Produksi Terhadap Pendapatan Bawang Merah}

Pengaruh Faktor-faktor produksi Terhadap Pendapatan bawang merah di Desa Lapandewa Kaindea Kecamatan Lapandewa. Model regresi yang diperoleh adalah :

$$
Y=36,571+1.197 X_{1}+36.776 X_{2}
$$

Dari model di atas diperoleh interprestasi sebagai berikut:

1. Setiap terjadi peningkatan luas lahan selama setahun, terjadi pula peningkatan pendapatan sebesar Rp. 1.197,-.

2. Setiap terjadi peningkatan biaya benih selama musim tanam, terjadi pula peningkatan pendapatan sebesar Rp. 36.776-.

Hasil regresi diperoleh Adjusted R2 sebesar 0,981 Hal ini berarti faktor-faktor produksi (luas lahan dan benih) memberikan pengaruh sebesar 98,10\% saja, sisanya dipengaruhi oleh faktor lain yang tidak dibahas dalam penelitian ini.

Dari hasil uji $F$ dihasilkan $F_{\text {hitung }}$ sebesar 493,506 (lebih kecil dari $F_{\text {tabel }}=2,90$ ) dengan signifikasi sebesar 0,000 (lebih besar dari $\alpha=0,05$ ). Sehingga dapat disimpulkan bahwa 


\section{Journal of Agribusiness Media}

Vol. 1 Issue 1, November 2017

P-ISSN: 2527-8479

$\mathrm{H}_{1}$ diterima dan $\mathrm{H}_{0}$ ditolak, bahwa faktor-faktor produksi secara serempak berpengaruh nyataterhadap pendapatan petani bawang merah.

Hasil uji t. Dapat pula dilihat bahwa faktor-faktor produksi, baik luas lahan dan benih berpengaruh nyata terhadap pendapatan. Hai ini dapat kita ketahui dari nilai thitung kedua faktor tersebut lebih kecil daripada $t_{\text {tabel }}(2,04)$. Hasil analisis dapat dilihat pada Tabel Tabel 3. Pengaruh Faktor-Faktor Produksi Terhaap Pendapatan Bawang Merah Di Desa Lapandewa Kaindea, 2015.

\begin{tabular}{|c|c|c|c|c|c|c|}
\hline & \multirow{3}{*}{ Model } & \multicolumn{2}{|c|}{ Unstandardized Cofficients } & \multirow{3}{*}{$\begin{array}{c}\begin{array}{c}\text { Standardized } \\
\text { Coefficients }\end{array} \\
\text { Beta } \\
\end{array}$} & \multirow{3}{*}{$\mathrm{T}$} & \multirow{3}{*}{ Sig } \\
\hline & & & & & & \\
\hline & & B & Std. Error & & & \\
\hline \multirow[t]{6}{*}{1} & (Constant) & $36,571189819,627$ & 331217,082 & & 3,592 &, 000 \\
\hline & $\begin{array}{ll}X_{1} & \text { (Luas } \\
\text { Lahan) } & \\
\end{array}$ & 1,197 & ,193 & ,211 & 6,191 & 0,000 \\
\hline & $\mathrm{X}_{2}$ (Benih) & 36,776 & 1,345 &, 782 & 27,344 & ,000 \\
\hline & $\mathrm{R}^{2}=0,981$ & & & & & \\
\hline & $\begin{array}{l}F_{\text {hitung }} \\
493,506\end{array}$ & & & & & \\
\hline & $\mathrm{Ft}_{\mathrm{abel}}=2,90$ & & & & & \\
\hline
\end{tabular}

Sumber: analisis data hasil SPSS versi 19.0

Penyebab nyata yangmempengaruhi kedua variabel tersebut dikarenakan hal yang sama pada analisis pengaruh faktor-faktor produksi terhadap pendapatan. Pada dasarnya faktor yang mempengaruhi pendapatan adalah harga produksi tersebut. Semakin tinggi jumlah produksi dan harga tentu saja kan meningkatkan pendapatan, dan sebaliknya. Hal ini pula disebabkan oleh adanya hama dan penyakit tanarnan, tingginya harga pupuk, kelangkaan pupuk bersubsidi dan pupuk palsu. Ini pula diperkuat pendapat Hal ini pula ini diperkuat pendapat Cahyono (1996), mengemukakan bahwa pendapatan dalam usahatani ada dua maeam yaitu pendapatan kotor dan pendapatan bersih (keuntungan). Pedapatan kotor usahatani yaitu keseluruhan hasil atau nilai uang dari usahatani. Pendapatan kotor usahatani dikurangi dengan biaya menghasilkan atau keseluruhan jumlah korbanan, atau merupakan selisih antara harga produk ditingkat petani dengan harga pokok dikalikan dengan jumlah produk usahatani. Ini pula dipertegas oleh Kepala Pertanian Kecamatan Lapandewa menyatakan mayoritas petani bawang merah di Kecamatan Lapandewa tidak menggunakan pupuk dan obat-obatan serta tanah yang mereka usahakan adalah tanah adat (Hasil Wawancara dengan La Kompa, 20 Juli 2015).

\section{KESIMPULAN DAN SARAN}

\section{a. Kesimpulan}

Berdasarkan keseluruhan uraian hasil penelitian, maka dapat disimpulkan sebagai berikut:

1. Faktor-faktor produksiberupa biaya (luas lahan dan benih) berpengaruh nyata terhadap pendapatanusahatani bawang merah.

2. Nilai Adjusted $\mathrm{R}^{2}$ sebesar 0,981 Hal ini berarti faktor- faktor produksi berupa (luas lahan dan benih) memberikan pengaruh sebesar $98,10 \%$ saja, sisanya dipengaruhi oleh faktor lain yang tidak dibahas dalam penelitian ini. 


\section{Journal of Agribusiness Media}

Vol. 1 Issue 1, November 2017

P-ISSN: 2527-8479

\section{b. Saran}

Bertolak dari hasil penelitian tersebut, maka dapat disarankan adalah sebagai berikut:

1. Diharapkan kepada petaniagar lebih selalau mencari informasi tentang pengetahuan dan wawasannya usahatani yang dikelolannya, terutama dalam hal pengendalian hama dan penyakit tanaman serta altematif pupuk organik.

2. Di pihak pemerintah diharapkan memberikan perhatian khusus kepada petani, baik itu berupa penanganan masaiah harga pupuk, distribusi pupuk maupun pupuk palsu.

\section{DAFTAR PUSTAKA}

Achmad, 2003. Manajemen Agribisnis. Penerbit Erlangga. Jakarta.

Agus Andoko, 2005, Budidaya Padi secara Organik, Swadaya, Jakarta.

Anonim, 1993, Agribisnis-Seri VII, Badan Diklat Pertanian RI, Jakarta.

Badan Pusat Statistik 2014. Buton Dalam Angka 2014. Kantor Badan Pusat Statistik Kabupaten Buton. Pasarwajo.

Dinas Pertanian Kabupaten Buton, 2012-2014. Laporan Tahunan Dinas Pertanian Kabupaten Buton. Pasarwajo.

Delianov, 1994. Pengembangan Kompetensi Individu SDM. Penerbit BPFE, Yogyakarta.

Hasan, M., 2002. Pokok-Pokok Materi Statistik, Edisi ke-2. Bumi Aksara. Jakarta.

Husein S., dan Sri Widodo, 2000. Ekonomi Pertanian. Universitas Muhammadyah Malang Press, Malang.

Mubyarto, 1995. Pengantar Ekonomi Pertanian. LP3ES, Jakarta.

Prawirokusumo. S., 1990. IImu Usahatani. Edisi 1. BPFE, Yogyakarta.

Sadono Sukimo, 2000. Teori Ekonomi Mikro. Penerbit Tarsito, Bandung.

Sapuan, 1999, Pendapatan dan Biaya Usahatani. Universitas Gadjah Mada, Yogyakarta.

Sayogyo, 1998. Ilmu Usaha Tani. Penebar Swadaya, Jakarta.

Soekartawi, 1990. Teori Ekonomi Produksi dengan Pokok Bahasan, Analisis Fungsi CobbDouglas. Rajawali Press. Jakarta. , 2001. Agribisnis Teori dan Aplikasinya Cetakan ke-6. PT. Raja Grafindo Persada. Jakarta.

, 2002. Prinsip Ekonomi Pertanian (Edisi Revisi). PT. 